\title{
Pre-existing spatial patterns in fish abundances influence species-specific responses in a Caribbean marine reserve
}

\author{
Mandy Karnauskas*, Brittany E. Huntington, Elizabeth A. Babcock, Diego Lirman \\ Rosenstiel School of Marine and Atmospheric Science, Department of Marine Biology and Fisheries, University of Miami, \\ Miami, Florida 33149, USA
}

\begin{abstract}
No-take marine reserves have been used to promote biodiversity conservation and have increasingly been implemented with the goal of rebuilding depleted fish stocks. Yet, marine reserves may cause some species to decrease in abundance while others increase, in part because species are not equally impacted by the effort displaced from the reserve into surrounding fished areas. We evaluate temporal patterns in the abundance and distribution of reef fishes at Glover's Atoll, Belize, where a no-take reserve was enforced in 1998. For the set of commercial species investigated in our study, the most important variable in predicting species responses to reserve protection was the prereserve spatial distribution of fishes with respect to reserve boundaries. Variation in species responses to protection could not be attributed to benthic habitat degradation, but maximum body length and trophic level were both positively correlated with response to protection. We suggest that reserve implementation caused mortality rates to increase for some fish species that were originally distributed in higher abundances outside reserve boundaries, leading to declines in abundance in these populations. These findings highlight the importance of incorporating knowledge on spatial distributions of fishes when designing and monitoring marine reserves. Our methods can be used by reserve managers to predict the responses of individual species to protection at the time of reserve implementation, thereby facilitating agreement between the expectations of fishery managers and the needs of stakeholders.
\end{abstract}

KEY WORDS: Marine protected area design $\cdot$ Spatial heterogeneity $\cdot$ Coral reef fisheries $\cdot$ Fishery management $\cdot$ Commercial species

\section{INTRODUCTION}

Marine reserves, or areas closed to fishing, have commonly been implemented to conserve biodiversity of ecosystems and have received more recent attention in regard to their potential ability to conserve fish stocks. It is hypothesized that reserves can provide benefits to surrounding fished areas through spillover of larvae and adults (Halpern 2003, Russ et al. 2004), and a number of empirical studies demonstrate these effects (Goñi et al. 2008, Harmelin-Vivien et al. 2008, Stobart et al. 2009). However, measured responses are highly variable between reserves and between species (Côté et al. 2001, Micheli et al. 2004, Lester et al. 2009,
Maliao et al. 2009). The lack of consensus regarding species-specific responses to reserve protection prevents specific predictions from being made upon reserve implementation (Edgar \& Stuart-Smith 2009). This lack of predictability has limited the use of reserves as effective management tools, as managers need to ensure that reserve effects are aligned with stakeholder interests (Halpern \& Warner 2003).

It is expected that fishes with smaller home ranges (Kramer \& Chapman 1999), limited larval dispersal (Botsford et al. 2003, 2008), in higher trophic levels (Halpern 2003), and those intensively exploited prior to reserve implementation (Micheli et al. 2004) will respond more positively to reserve protection. How- 
ever, some studies have noted simultaneous increases and decreases in different species within the same reserve, even for species that appear to have similar life histories and movement behaviors (Côté et al. 2001, Micheli et al. 2004). Fish population responses to reserves depend on whether the productivity of the protected biomass can offset the effects of fishing displacement (Halpern et al. 2004), and these parameters are affected by the distribution of the fishes with respect to reserve boundaries (Kellner \& Hastings 2009). Several authors have suggested that variation in species responses may be due to differences in distributions and exploitation levels before the reserves were implemented (Côté et al. 2001, Lester et al. 2009); however, these predictions have not been empirically tested in studies of reserve effects on fish populations.

High levels of natural variability in fish communities have been found to exist on scales of 5 to $10 \mathrm{~km}$ in rocky reef systems (García-Charton et al. 2004, Ordines et al. 2005) and on even smaller scales of $<1 \mathrm{~km}$ in coral reef systems (Grober-Dunsmore et al. 2006, Huntington et al. 2010). This heterogeneity in the distribution of fish species is considered in the design and evaluation of reserves only in that reserves tend to be sited in locations with high abundance or high catch rates of species of interest (Lester et al. 2009) and that fished reference sites for monitoring reserve impacts are generally sited in areas of similar habitat (e.g. Harborne et al. 2008a). Marine reserves are often established with no explicit analysis of the potential for fishing effort displaced from marine reserves to differentially impact fish species with different habitat preferences and spatial distributions, although such analyses are common for the development of time/area closures for fisheries management (e.g. Azadivar et al. 2009). Quantifying the extent and scale of spatial variability in fish abundance is therefore critical to reserve design and monitoring, to ensure that fish populations with distributions favoring unprotected zones do not undergo increased mortality.

In the present study we examine potential causes for varying responses of species to protection in a managed area with a no-take reserve. We investigate 4 potential mechanisms for the observed temporal changes: (1) spatially explicit habitat changes that may affect different species differently, (2) life-history characteristics (specifically, maximum body length and trophic level), (3) differing susceptibility of fish species to the fishery, and (4) differences between species in the effect of the reserve on fishing mortality due to initial spatial distribution of fish of each species. Maximum body length is correlated with a number of lifehistory characteristics thought to affect species' responses to protection, such as home range (Kramer \& Chapman 1999), reproductive output (Micheli et al.
2004), and susceptibility to overexploitation (Jennings et al. 1999), and therefore serves as a useful indicator of these covariable attributes. The ultimate aim of our paper is to understand why some species increased in abundance in the $10 \mathrm{yr}$ period after the implementation of the reserve, while others decreased over the same period.

\section{MATERIALS AND METHODS}

Study site. The Glover's Reef Marine Reserve (GRMR) is located on Glover's Reef Atoll, 1 of 3 remote atolls in Belize located outside the Mesoamerican Barrier Reef. Approximately one-fifth (7280 ha) of the atoll's 35000 ha was designated as a no-fishing area in 1993, and enforcement of the zone began in 1998 (Garaway \& Esteban 2002). The isolated atoll is suited for such a study on responses of fish populations to reserve protection. The atoll's lagoon contains $>800$ patch reefs of varying spatial configurations and habitat composition types, ranging in size from roughly 240 to $28800 \mathrm{~m}^{2}$ (Wallace 1975). The lagoon is completely enclosed by the reef crest, with the exception of large channels in the northeast and south and a small channel in the southeast (Fig. 1). Isolation prevents the site from being highly exposed to land-based stressors, and it is only seasonally influenced by terrestrial runoff (Chérubin et al. 2008). Immigration to and emigration out of the atoll are likely to be limited; acoustic telemetry studies have showed that larger species such as Nassau grouper (Starr et al. 2007) and nurse sharks (Pikitch et al. 2005) are largely resident on the atoll and spawning of several large commercial species (Mycteroperca bonaci, M. venenosa, M. tigris, and Epinephelus striatus) has been documented to occur within the atoll (Heyman \& Requena 2002, Starr et al. 2007). Finally, a distinct group of fishers uses the atoll, and gear types (only spear, handline, and free diving were allowed in the managed area from 1998 to 2009) and numbers of fishers have remained relatively stable since reserve implementation (Lizama \& Gibson 2006). In the present study, we therefore make the assumptions that: (1) the system is closed, with the exception of possible larval recruitment from other areas and (2) changes in the system are a result of mortality due to fishing, management actions, natural processes, and stochastic disturbances.

Data collection. At the inception of the reserve at Glover's Reef, existing fish and benthic communities at 150 patch reef sites were assessed across the lagoon in 1998 and 1999 (Thoney 2001). Ten years later, in 2008 and 2009, we repeated this assessment using the same methods on a group of 56 randomly selected patches included in the original survey by Thoney (2001). For 


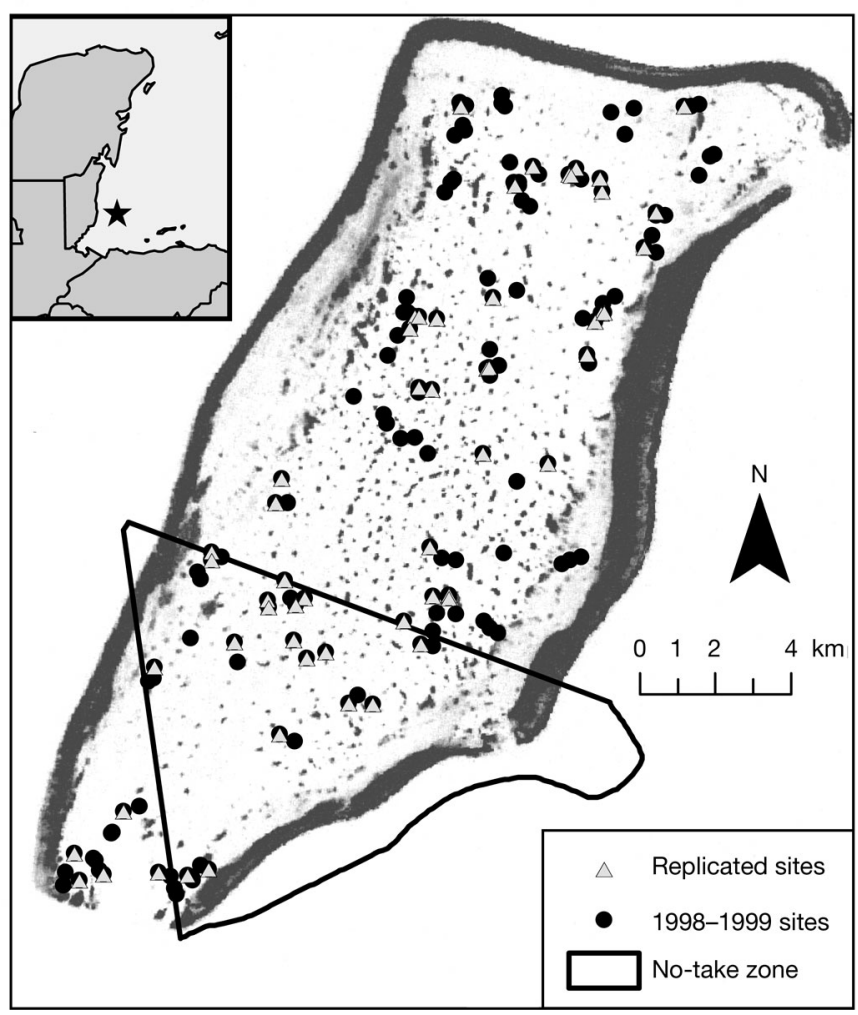

Fig. 1. Satellite image of Glover's Reef Atoll, Belize. Emergent reef encloses the atoll lagoon, with the exception of 2 large channels in the south and northeast of the atoll and a smaller corridor to the southeast. Patch reefs and shallow sand banks both appear in gray

simplicity, we hereafter refer to the 1998 to 1999 pooled data set as the 'before' data set and the 2008 to 2009 pooled observations as the 'after' data set. For both surveys, fish abundance data were collected using the stationary point survey method (Bohnsack \& Bannerot 1986) using a $5 \mathrm{~m}$ cylinder radius, with 5 replicates per patch located on the $N, E, S$, and W sides of the patch at the $3 \mathrm{~m}$ contour and center of the patch. In 1998 to 1999, benthic cover of patch reefs was determined using the line intercept transect method (cover recorded every $10 \mathrm{~cm}$ along $10 \mathrm{~m}$ transects, 4 replicates per patch). In 2008 to 2009, this method was modified to reduce necessary diving time through the use of digital photography (Dumas et al. 2008), which has been shown to be comparable to the line intercept transect method for abundant substrate categories (Leujak \& Ormond 2007). Images were taken $0.5 \mathrm{~m}$ above the benthos at $2 \mathrm{~m}$ intervals along 2 transects spanning the long and short axes of the patch. Percent coverage of benthic organisms was calculated using random point intercept methods in CPCe software (Kohler \& Gill 2006) averaged across 20 randomly selected images per site, with 50 random points per image. While covariation among sample points is higher using the line-intercept transect method than in our digital photo method, the influence of covariation is reduced in the 1998 to 1999 data set because benthic cover per site was averaged across multiple, independent $10 \mathrm{~m}$ long transects. Other environmental variables were generated using $4 \mathrm{~m}$ resolution IKONOS images and ArcGIS (Environmental Systems Research Institute), including: patch area, area of hard bottom habitat within a specified radius around the site (200 m, $500 \mathrm{~m}$, and $1 \mathrm{~km}$ buffers), nearest neighboring patch, perimeter of the patch, and distance of the patch from a large channel (northeastern or southern channels). Area and perimeter metrics were calculated by generating polygons in ArcGIS, which approximated the shape of the hard substrate visible in the IKONOS images, and by extracting the area and perimeter of the polygons (see Huntington et al. 2010 for details of the methods). These environmental variables were found to be important in influencing fish communities in a previous study (Huntington et al. 2010).

Data analyses. We considered 4 possible causes for variation in species-specific reserve responses over time: (1) differing species responses to changes in habitat, (2) differences in life-history characteristics (specifically, maximum body size, and trophic group), (3) differing importance of fish species to the fishery, and (4) initial distribution of fishes relative to the reserve, which influenced their relative availability to the fishery after the reserve was established. We first quantified temporal changes in fish abundance and benthic habitat (specifically, coral cover) and developed a metric for initial spatial distributions of fish populations. We then explored relationships between life-history characteristics, original spatial distributions and temporal changes through a range of multivariate techniques. Fish abundances were log transformed, and percentages of benthic cover variables were arcsine square-root transformed. When assumptions of normality and homoscedacity were met, parametric tests were used, and, when not met, the non-parametric equivalents were used.

Changes in individual species abundance by site (number of fish of the species seen per replicate averaged across the 5 replicates at each site) between the before and after periods were tested using paired $t$-tests or Wilcoxon signed-rank tests. For these comparisons, only the 56 replicate sites were paired in order to remove the potential influence of spatial variability. In cases where there were zero observations in 1 temporal period, a binomial presence-absence test was used for comparisons (Conover 1971). Changes in habitat quality (represented by percent hard coral cover) over time were also tested using paired $t$-tests of percent hard coral cover on the 56 replicate sites. To test the effects of habitat change on species' temporal 
responses, we regressed the change in abundance of each species separately against change in hard coral cover at each site.

To identify the principal ecological factors affecting fish community composition in the system, canonical correspondence analysis (CCA) was used. The analysis was performed on the full set of 150 sites in the before data set to look at these effects in the absence of spatial management. Before the analysis was carried out, environmental variables were inspected for collinearity, and, for pairs of variables with $\mathrm{r}^{2}$ values $>0.90$, the least ecologically meaningful variable was removed. Fish species with $<5 \%$ occurrence rates were removed to avoid overweighting of rare species. The resulting analysis was performed on a matrix of 36 fish species and 150 sites against 16 continuous environmental predictor variables (patch area, area of reef within $200 \mathrm{~m}$, $500 \mathrm{~m}$, and $1 \mathrm{~km}$ radii, nearest neighboring reef, coral species richness, distance from channels, and percent benthic cover of hard coral, soft coral, seagrass, crustose coralline algae, algae, invertebrates, sponge, sand, and rock). Forward stepwise regression was used to determine the best model; the initial model contains the most significant explanatory variable, and further variables are added based on significance of partial F-tests. Permutation tests (999 runs) were run on the models to test: (1) the significance of the environmental factors in describing the fish community and (2) the significance of the axes. These tests randomize the matrices and rerun the CCA with these randomized values, and the pvalue is defined as the percentage of runs which produce: (1) inertial values higher than the experimental value and (2) eigenvalues higher than the experimental eigenvalue ( $\mathrm{R}$ Version 2.7.2, vegan library; R Core Development Team 2009).

Information on maximum fork length and trophic level for each species were taken from FishBase (Froese $\&$ Pauly 2010). The fish species were also categorized by assuming that large, commercially valuable species would be more susceptible to exploitation. The fishing susceptibility categories were: (5) very large bodied, very highly sought species (large groupers, barracuda, and hogfish); (4) large, highly sought species (large snappers, small groupers, large parrotfishes, triggerfishes); (3) medium sized, sometimes sought species (grunts, porgies, small parrotfishes, small snappers); (2) smaller, opportunistically taken species (angelfishes, small jacks); (1) species only rarely documented in the catch (goatfishes, small grunts, mojarras); and (0) species not documented in the catch (tangs, butterflyfishes, trumpetfish, chub, lizardfish, small wrasses). Species were categorized based on information on catch composition, commercial value, and maximum length (Babcock \& Coleman 2010). As a metric of initial distribution of fish species, we calculated, from the before data set, the initial difference in abundance between reserve and non-reserve areas for each species (defined as $N_{\text {inside }}-N_{\text {outside, }}$ where $N$ is the average abundance per patch in each location).

To test the relative importance of the potential causes for species-specific responses, the changes in abundance of each fish species inside and outside the reserve were modeled using a generalized linear model with the 4 explanatory variables: $x_{1}=$ maximum body length, $x_{2}=$ trophic level, $x_{3}=$ the metric of susceptibility to fishing, and $x_{4}=$ initial inside versus outside differences in abundance. A logistic regression was applied where the response variable was the proportion of sites with a positive temporal response in abundance (defined as $p$, the fraction of the sites that showed a positive change in abundance), such that:

$$
\operatorname{logit}(p)=\beta_{0}+\beta_{1} x_{1}+\beta_{2} x_{2}+\beta_{3} x_{3}+\beta_{4} x_{4}
$$

We ran these analyses separately for: (1) the 39 sites located outside the reserve and (2) the 17 sites within the reserve, to elucidate processes unique to the fished and protected areas. The models were built first for the full set of 36 species with occurrence rates of $>5 \%$ and then for only the 27 commercial species (defined as all fishing susceptibility categories except 0 ) in the data set with occurrence rates of $>5 \%$. For all models, Akaike's information criterion (AIC) was used to find the best model to predict species temporal responses; the model with the lowest AIC value was chosen. Models with $\triangle$ AIC values $<2$ are supported by the data, while $\triangle$ AIC values $>10$ indicate that the model is not supported (Burnham \& Anderson 2002).

For logistic regressions, p-values were calculated based on the chi-squared statistic. All analyses were done in $\mathrm{R}$ Version 2.7.2; multivariate analyses were done using the Vegan library (R Core Development Team 2009).

\section{RESULTS}

\section{Temporal changes in abundance across both fished and reserve sites}

A total of 41 species were counted in both before and after data sets, including 31 commercial species and 10 non-fished species. Of these 41 species, 36 species had occurrence rates of $>5 \%$ on patch reefs in both data sets combined. Fifteen species showed significant declines in abundance across the atoll during the $10 \mathrm{yr}$ period, and 8 species showed significant increases (Table 1, Fig. 2). Species increasing in abundance were all commercially valuable species, while the 15 species showing decreases included 5 non-commercial species. 


\section{Environmental factors related to initial community composition}

Stepwise CCA of the 36 species with occurrence rates $>5 \%$ for all 150 sites in the before data set produced a final model with 7 environmental variables: patch area, area of reef within a $500 \mathrm{~m}$ buffer, percent seagrass, percent hard coral, percent soft coral, coral species richness, and distance from channel (Fig. 3). Significant relationships existed between the 7 envi- ronmental variables and the fish community $(\mathrm{p}<$ 0.001), and permutation tests showed that the first axis was significant $(p<0.001)$. On the first axis, which explained $49.6 \%$ of the variation, the channel distance variable was the most significant (loading score first axis $=-0.81)$. Seagrass cover was the second most important variable on the first axis (loading score first axis $=-0.59$ ) and the most important on the second axis (loading score second axis $=0.56$ ). The 3 physical variables alone (channel distance, patch area, and area in

Table 1. Species responses averaged over sites across the entire atoll over the $10 \mathrm{yr}$ period. Densities (fish per $5 \mathrm{~m}$ diameter cylinder) are average abundance per patch reef averaged over the entire atoll before and after the reserve was implemented. +: significant increase from 1999 to 2009; -: significant decrease, 0: no significant change. NA: not applicable. The p-values for paired $t$-tests of 56 sites: ${ }^{\mathrm{p}}$ parametric $t$-test, ${ }^{\mathrm{n}}$ non-parametric Wilcoxon test, ${ }^{\mathrm{b}}$ binomial presence-absence test

\begin{tabular}{|c|c|c|c|c|c|c|c|}
\hline Species & Common name & $\begin{array}{l}\text { Fishing } \\
\text { pressure }\end{array}$ & $\begin{array}{c}1999 \\
\text { density }\end{array}$ & $\begin{array}{c}2009 \\
\text { density }\end{array}$ & $\begin{array}{l}\text { Decrease/ } \\
\text { increase }\end{array}$ & $\begin{array}{l}\text { Percent } \\
\text { change }\end{array}$ & $\mathrm{p}$ \\
\hline \multicolumn{8}{|l|}{ Commercial species } \\
\hline Balistes vetula & Queen triggerfish & 4 & 0.01 & 0.00 & 0 & -100 & $0.27^{\mathrm{b}}$ \\
\hline Canthidermis sufflamen & Ocean triggerfish & 4 & 0.10 & 0.00 & - & -100 & $0.03^{\mathrm{b}}$ \\
\hline Cephalopholis fulva & Coney & 4 & 0.02 & 0.00 & - & -100 & $0.01^{\mathrm{b}}$ \\
\hline Epinephelus cruentatus & Graysby & 1 & 0.18 & 0.16 & 0 & -10 & $0.62^{\mathrm{n}}$ \\
\hline Epinephelus guttatus & Red hind & 4 & 0.11 & 0.10 & 0 & -11 & $0.95^{\mathrm{n}}$ \\
\hline Epinephelus striatus & Nassau grouper & 5 & 0.01 & 0.00 & 0 & -67 & $0.27^{\mathrm{n}}$ \\
\hline Mycteroperca bonaci & Black grouper & 5 & 0.00 & 0.03 & + & NA & $<0.001^{\mathrm{b}}$ \\
\hline Haemulon aurolineatum & Tomtate & 1 & 0.01 & 0.00 & 0 & -100 & $0.27^{\mathrm{b}}$ \\
\hline Haemulon flavolineatum & French grunt & 1 & 2.41 & 1.20 & - & -50 & $0.02^{\mathrm{p}}$ \\
\hline Haemulon plumieri & White grunt & 3 & 7.16 & 6.26 & 0 & -12 & $0.33^{\mathrm{p}}$ \\
\hline Haemulon sciurus & Bluestriped grunt & 3 & 1.19 & 0.39 & - & -67 & $0.02^{\mathrm{p}}$ \\
\hline Holacanthus ciliaris & Queen angelfish & 2 & 0.14 & 0.16 & 0 & 17 & $0.28^{\mathrm{n}}$ \\
\hline Holacanthus tricolor & Rock beauty & 1 & 0.03 & 0.00 & - & -94 & $0.03^{\mathrm{p}}$ \\
\hline Pomacanthus arcuatus & Gray angelfish & 2 & 0.36 & 0.51 & + & 40 & $0.07^{\mathrm{n}}$ \\
\hline Pomacanthus paru & French angelfish & 2 & 0.16 & 0.01 & - & -93 & $<0.001^{\mathrm{n}}$ \\
\hline Lutjanus griseus & Gray snapper & 3 & 0.06 & 0.22 & + & 251 & $0.03^{\mathrm{n}}$ \\
\hline Lutjanus analis & Mutton snapper & 4 & 0.08 & 0.12 & 0 & 49 & $0.17^{\mathrm{n}}$ \\
\hline Lutjanus apodus & Schoolmaster snapper & 3 & 0.37 & 0.23 & 0 & -38 & $0.22^{\mathrm{n}}$ \\
\hline Lutjanus mahagoni & Mahogany snapper & 3 & 0.08 & 0.01 & - & -93 & $0.04^{\mathrm{n}}$ \\
\hline Lutjanus synagris & Lane snapper & 3 & 0.07 & 0.49 & + & 580 & $<0.01^{\mathrm{n}}$ \\
\hline Ocyurus chrysurus & Yellowtail snapper & 3 & 4.67 & 4.93 & 0 & 6 & $0.55^{\mathrm{p}}$ \\
\hline Scarus coeruleus & Blue parrotfish & 4 & 0.02 & 0.00 & - & -100 & $0.08^{\mathrm{b}}$ \\
\hline Scarus vetula & Queen parrotfish & 4 & 0.08 & 0.00 & - & -100 & $<0.001^{\mathrm{b}}$ \\
\hline Sparisoma aurofrenatum & Redband parrotfish & 3 & 3.02 & 3.57 & 0 & 18 & $0.16^{\mathrm{p}}$ \\
\hline Sparisoma viride & Stoplight parrotfish & 4 & 2.00 & 0.68 & - & -66 & $<0.001^{\mathrm{p}}$ \\
\hline Calamus calamus & Saucereye porgy & 3 & 0.39 & 1.06 & + & 169 & $<0.001^{\mathrm{n}}$ \\
\hline Caranx ruber & Bar jack & 2 & 1.95 & 2.44 & + & 25 & $<0.01^{\mathrm{p}}$ \\
\hline Lachnolaimus maximus & Hogfish & 5 & 0.04 & 0.13 & + & 220 & $<0.01^{\mathrm{n}}$ \\
\hline Sphyraena barracuda & Barracuda & 5 & 0.14 & 0.03 & 0 & -76 & $0.25^{\mathrm{n}}$ \\
\hline Pseudupeneus maculatus & Spotted goatfish & 1 & 0.04 & 0.08 & + & 120 & $0.05^{\mathrm{n}}$ \\
\hline Gerres cinereus & Yellowfin mojarra & 1 & 0.09 & 0.04 & 0 & -52 & $0.89^{\mathrm{n}}$ \\
\hline \multicolumn{8}{|l|}{ Non-commercial species } \\
\hline Acanthurus bahianus & Ocean surgeonfish & 0 & 3.15 & 1.91 & 0 & -39 & $0.50^{\mathrm{p}}$ \\
\hline Acanthurus coeruleus & Blue tang & 0 & 4.46 & 2.07 & - & -54 & $<0.001^{\mathrm{p}}$ \\
\hline Aulostomus maculatus & Trumpetfish & 0 & 0.02 & 0.01 & 0 & -65 & $0.21^{\mathrm{n}}$ \\
\hline Bodianus rufus & Spanish hogfish & 0 & 0.00 & 0.01 & 0 & NA & $0.27^{\mathrm{b}}$ \\
\hline Chaetodon capistratus & Foureye butterflyfish & 0 & 2.16 & 0.71 & - & -67 & $<0.001^{\mathrm{p}}$ \\
\hline Chaetodon ocellatus & Spotfin butterflyfish & 0 & 0.19 & 0.07 & - & -63 & $0.03^{\mathrm{n}}$ \\
\hline Chaetodon striatus & Banded butterflyfish & 0 & 0.04 & 0.03 & 0 & -30 & $0.63^{\mathrm{n}}$ \\
\hline Kyphosus sectatrix & Bermuda chub & 0 & 0.04 & 0.08 & 0 & 88 & $0.67^{\mathrm{n}}$ \\
\hline Mulloidichthys martinicus & Yellow goatfish & 0 & 0.46 & 0.14 & - & -71 & $0.04^{\mathrm{n}}$ \\
\hline Synodus intermedius & Sand diver & 0 & 0.09 & 0.00 & - & -100 & $<0.01^{\mathrm{b}}$ \\
\hline
\end{tabular}




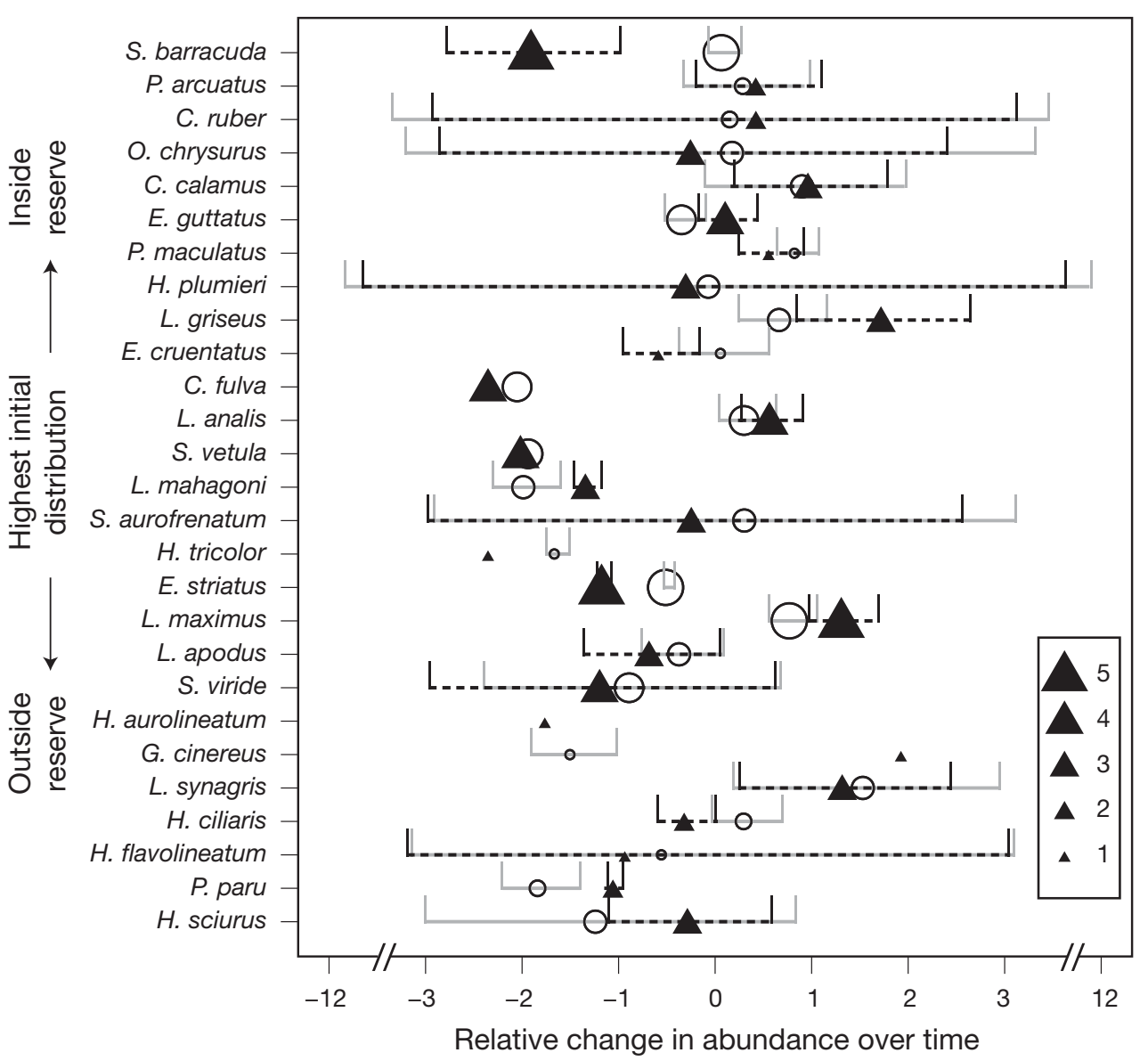

Fig. 2. Changes in relative abundance [average (abundance $_{\text {site } 2009 \text { - abundance- }}$ site 1999)/average abundance of both periods] inside and outside the reserve for each commercial species (full taxonomic names, see Table 1). Species are sorted from those with the highest initial distributions outside the reserve (bottom) to those with the highest initial distributions inside the reserve (top). Open circles and light gray bars denote changes in the fished zone; closed triangles and black dashed bars denote changes in the reserve. Confidence intervals are $\pm 1 \mathrm{SD}$. Size of $O$ or $\boldsymbol{\Delta}$ indicates thefishing pressure category (see legend)
$500 \mathrm{~m}$ buffer) described $25 \%$ of the total variability in the fish community composition, whereas the 4 biotic variables alone (percent seagrass, percent hard coral, percent soft coral, and coral species richness) described $19 \%$ of the variability.

\section{Potential explanations for differential changes in abundance over time}

Percent coral cover loss in terms of absolute change in percent cover was higher for sites inside the reserve (average: $6.65 \%$ loss) in comparison to outside the reserve (average: $3.36 \%$ loss, $\mathrm{p}=0.08$ ). The relative loss in coral cover, defined as (change in percent cover/percent cover in 1999) was significantly greater in the reserve $(\mathrm{p}=0.006)$, with an average relative loss of coral inside the reserve of $55.0 \%$ and an average loss outside the reserve of $21.8 \%$. No significant regressions were found to exist between the changes in species abundance at each of the 56 patches and the change in coral cover at each patch for any of the 36 species.
Generalized linear models to test the relative importance of the potential causes of species-specific responses showed that all 4 factors (maximum body length, trophic level, susceptibility to fishing, and initial differences in abundance with respect to reserve boundaries) were predictive of temporal responses to some extent, although the relative importance of each factor was different for changes observed in reserve sites versus fished sites. We first report on the results for the 39 sites outside the reserve. For analysis of the full set of 36 species, the model with the lowest AIC value included the fishing susceptibility group ( $\mathrm{p}=$ $\left.3.7 \times 10^{-8}\right)$, maximum length $\left(p=1.5 \times 10^{-4}\right)$, and the initial differences in abundance $(p=0.02$, AIC $=$ 207.92; Table 2). Maximum length and fishing susceptibility explained larger percentages of the deviance (9.0 and $29.5 \%$, respectively). Positive responses generally in- creased with increasing fishing susceptibility, although the large decline of 2 large-bodied parrotfish (the queen parrotfish Scarus vetula and stoplight parrotfish Sparisoma viride) in Category 4 drove a decrease in the trend for this category. Also, for the set of 36 species, the full model including all 4 explanatory 


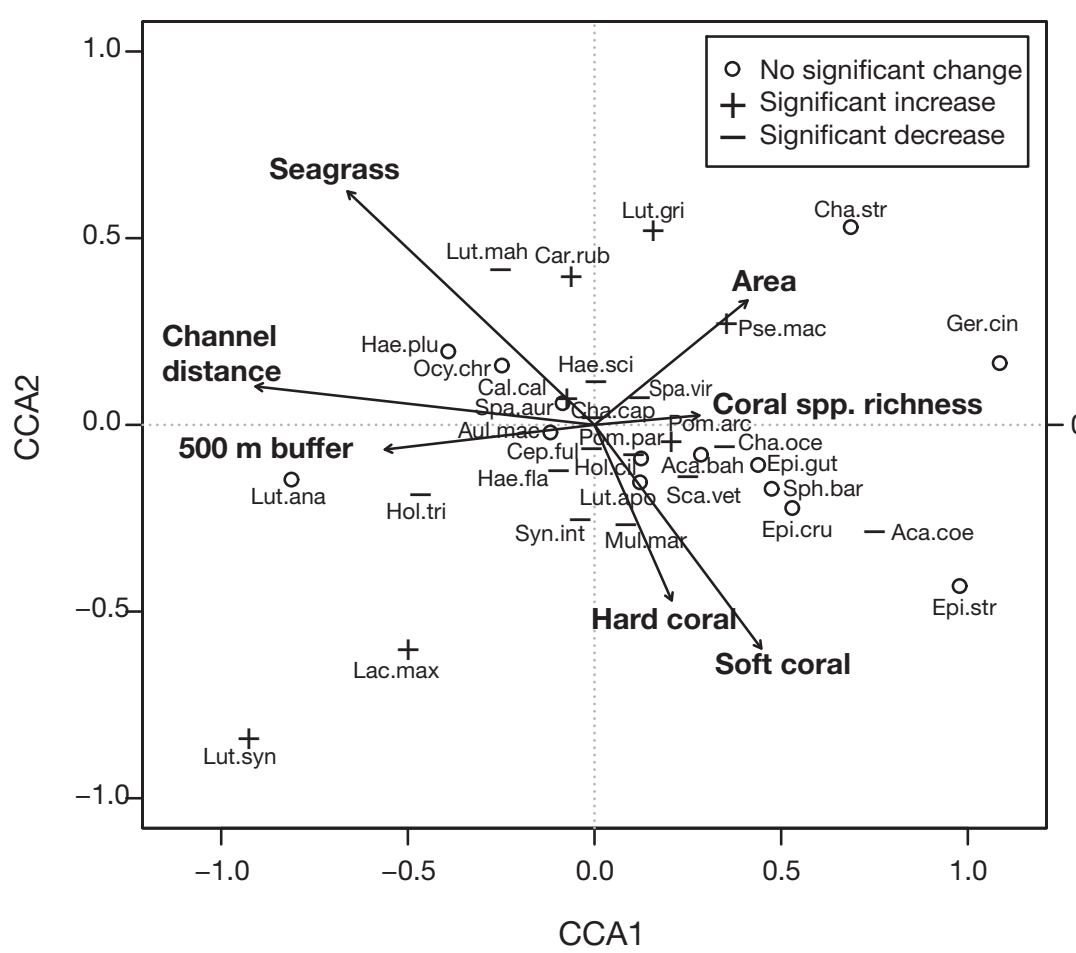

Fig. 3. Canonical correspondence analyses for the best-fit model of 7 environmental variables against 36 species; species labeled by name and temporal response type. See Table 1 for full taxonomic names

variables had a $\triangle$ AIC value of $<2$; however, the addition of the trophic level variable to the model was not significant ( $p=0.86$; Table 2). Maximum length and trophic level were both positively correlated with response, so that fishes with larger maximum fork lengths and belonging to higher trophic levels tended to show greater increases in abundance over time.

In the analysis of the 39 non-reserve sites for the 27 commercial species alone, the model with the lowest AIC value included only the fishing susceptibility grouping $(p=0.001)$ and the initial differences, which were highly significant $\left(\mathrm{p}=1 \times 10^{-7}\right.$, AIC = 145.70; Table 2, Fig. 2). Initial differences with respect to reserve boundaries explained a greater fraction of the deviance $(31.3 \%)$, and fishing susceptibility group explained $16.8 \%$ of the deviance. The model containing 3 variables: initial differences in abundance, fishing susceptibility, and trophic level, also had a $\triangle \mathrm{AIC}<2$ $(\mathrm{AIC}=147.48, \Delta \mathrm{AIC}=1.78)$, although the addition of trophic level was not significant $(\mathrm{p}=0.64)$. The full model including all 4 variables was also $<2$ $\triangle \mathrm{AIC}$ from the lowest model (AIC = $147.41, \Delta \mathrm{AIC}=1.72$ ), but the addition of maximum length to the model was not significant $(\mathrm{p}=0.15)$.

The same 4 factors (maximum body length, trophic level, susceptibility to fishing, and initial differences in abundance with respect to reserve boundaries) were also related to temporal responses at the 17 reserve sites. For the full set of 36 commercial and noncommercial species, the model with the lowest AIC value contained only the fishing susceptibility group $(\mathrm{p}=1 \times$ $10^{-4}, \mathrm{AIC}=155.02 ;$ Table 2 ), which explained $22.8 \%$ of the deviance. Abundance generally increased with fishing susceptibility, but with a slight drop in fishing susceptibility Category 4, again driven by decreases in the stoplight parrotfish Sparisoma viride. A drop in fishing Category 5 was also observed, due to trends in Sphyraena barracuda; the decline in abundance for this species was driven by large decreases at 2 sites located $<400 \mathrm{~m}$ from the reserve border. For the set of 36 species, alternative models with $\triangle$ AIC values $<2$ were produced by adding any of the other 3 factors,

Table 2. Summary of results from generalized linear models to predict responses of fish species to reserve protection based on 4 variables. ML: maximum body length; TL: trophic level; FS: susceptibility to fishing; ID: initial differences in abundance with respect to reserve boundaries. Variables are listed in order of those explaining the greatest amount of deviance to the least amount of deviance. The model with the lowest Akaike's information criterion (AIC) value, as well models with $\Delta$ AIC values $<2$, are shown

\begin{tabular}{|c|c|c|c|c|c|c|}
\hline \multirow[t]{2}{*}{ Zone } & \multicolumn{3}{|c|}{ Full set of 36 species } & \multicolumn{3}{|c|}{ Subset of 27 commercial species } \\
\hline & Model & AIC & $\Delta \mathrm{AIC}$ & Model & AIC & $\Delta \mathrm{AIC}$ \\
\hline \multirow{3}{*}{$\begin{array}{l}\text { Fished } \\
(\mathrm{n}=39 \text { sites })\end{array}$} & $\mathrm{FS}+\mathrm{ML}+\mathrm{ID}$ & 207.9 & 0 & $\mathrm{ID}+\mathrm{FS}$ & 145.7 & 0 \\
\hline & $\mathrm{FS}+\mathrm{ML}+\mathrm{ID}+\mathrm{TL}$ & 209.9 & 2.0 & $\mathrm{ID}+\mathrm{FS}+\mathrm{TL}+\mathrm{ML}$ & 147.4 & 1.7 \\
\hline & & & & $\mathrm{ID}+\mathrm{FS}+\mathrm{TL}$ & 147.5 & 1.8 \\
\hline \multirow{4}{*}{$\begin{array}{l}\text { No-take } \\
(\mathrm{n}=17 \text { sites })\end{array}$} & FS & 155.0 & 0 & $\mathrm{TL}+\mathrm{ID}$ & 119.5 & 0 \\
\hline & $\mathrm{FS}+\mathrm{TL}$ & 155.5 & 0.5 & $\mathrm{TL}+\mathrm{ID}+\mathrm{ML}$ & 119.8 & 0.4 \\
\hline & $\mathrm{FS}+\mathrm{ML}$ & 156.8 & 1.8 & $\mathrm{TL}+\mathrm{ID}+\mathrm{ML}+\mathrm{FS}$ & 120.0 & 0.6 \\
\hline & $\mathrm{FS}+\mathrm{ID}$ & 156.9 & 1.9 & & & \\
\hline
\end{tabular}


although none of these additional factors significantly improved model fit (fishing group + trophic level, $\triangle$ AIC $=0.52, \mathrm{p}=0.23$; fishing group + maximum length, $\Delta \mathrm{AIC}=1.75, \mathrm{p}=0.62 ;$ fishing group + initial differences, $\Delta \mathrm{AIC}=1.89, \mathrm{p}=0.74 ;$ Table 2). Correlations were in the same directions as those noted for the sites located outside of the reserve, i.e. fishes with greater initial density inside the reserve than outside the reserve, fishes with larger maximum fork lengths, and fishes belonging to higher trophic levels tended to show greater increases in abundance over time within the reserve.

For the subset of 27 commercial species, the best model to predict fish abundance responses inside the reserve included only trophic level $(p=0.01)$ and initial differences $(p=0.03$, AIC $=119.45$; Table 2). Trophic level explained $8.3 \%$ of the deviance, and initial differences in abundance explained only $6.5 \%$ of the deviance. The addition of maximum length to this 2variable model also resulted in a $\triangle \mathrm{AIC}<2$, but its effect was not significant $(p=0.20)$. Finally, the full model including all 4 explanatory factors resulted in a $\triangle \mathrm{AIC}<$ $2(\mathrm{AIC}=120.03, \Delta \mathrm{AIC}=0.58)$, but the addition of the fishing susceptibility group was not significant $(\mathrm{p}=$ 0.10 ). This full model explained only $26.5 \%$ of the variance in temporal responses in fish abundance at sites within the reserve (compared to a total $44.9 \%$ of variance explained in responses for sites in the fished zone).

\section{DISCUSSION}

Fish populations at Glover's Atoll showed varying responses to reserve protection, with 15 species showing significant decreases across the entire atoll over the $10 \mathrm{yr}$ period and 8 species showing significant increases. Responses of commercial species inside the reserve were driven mainly by trophic level, with increases in species' abundances associated with species of higher trophic levels. Outside the reserve, however, commercial species' responses were driven most significantly by the initial distribution of populations with respect to reserve boundaries. Species that were originally distributed with higher abundances outside the reserve suffered decreases over time at a greater number of sites in the fished area. The most likely explanation for the observed temporal patterns is that some species were more abundant in the area outside the reserve at the reserve's inception, and this could have caused additional mortality to occur in these species when fishing effort was displaced from the reserve to surrounding areas.

While trophic level and maximum length were found to sometimes be important in predicting species responses over time, these variables explained relatively small amounts of variation in responses and did not fully explain the inconsistencies that existed in the responses of species of similar sizes and trophic levels. Our results show these inconsistencies are most likely related to species' initial differences in spatial distribution with respect to the reserve boundaries. For example, the angelfish species Pomacanthus paru and $P$. arcuatus displayed opposite temporal changes in abundance. Initially, $P$. paru density was significantly greater outside the reserve ( $\mathrm{p}=0.03$; Fig. 4$)$, and it decreased in abundance over time by $93 \%(p<0.001)$. On the other hand, $P$. arcuatus was initially more abundant inside the reserve $(p=0.07$; Fig. 4$)$, and it increased in abundance over time by $40 \%(p=0.07)$. Both species are targeted by the fishery (Babcock \& Coleman 2010).

Displaced fishing effort appears to be the mechanism driving the species-specific responses observed in the fished area for commercial species. Glover's Reef is heavily fished (Lizama \& Gibson 2006), and it is likely that many species would have continued to decline in the absence of the reserve. Increases in abundance after reserve protection can only take place if the closed area is productive enough to offset increased fishing pressure outside the reserve (Halpern et al. 2004, Hiddink et al. 2006). Thus, a sufficient proportion of the biomass and spawning stock biomass must exist within the reserve to support potentially higher mortality rates; otherwise, reserve protection may result in decreases in abundance for species distributed predominantly in the fished area (Greenstreet et al. 2009, Kellner \& Hastings 2009).

The directions of temporal responses (increase or decrease) were generally related to initial distributions of fishes with respect to channel distance and seagrass cover. Species showing negative temporal responses are somewhat clumped towards the lower right (positive on Axis 1 and negative on Axis 2), meaning that they were originally more abundant near channels and in areas of lower seagrass cover. Only 1 species showing positive change in abundance over time occurred in this quadrat of the CCA biplot. The distance from channel gradient was found to be the most significant factor in explaining the fish community patterns. Channels may be subject to increased current strength, variability in environmental conditions, and increased food availability, among other possibilities. Channels are also likely to be the only entry route for large piscivorous fishes, and this may have an impact on trophic community structure in channel areas.

Regarding the environmental variables found to be important in structuring the pre-reserve fish community, abiotic factors such as channel distance, patch area, and amount of reef in a $500 \mathrm{~m}$ radius were found 


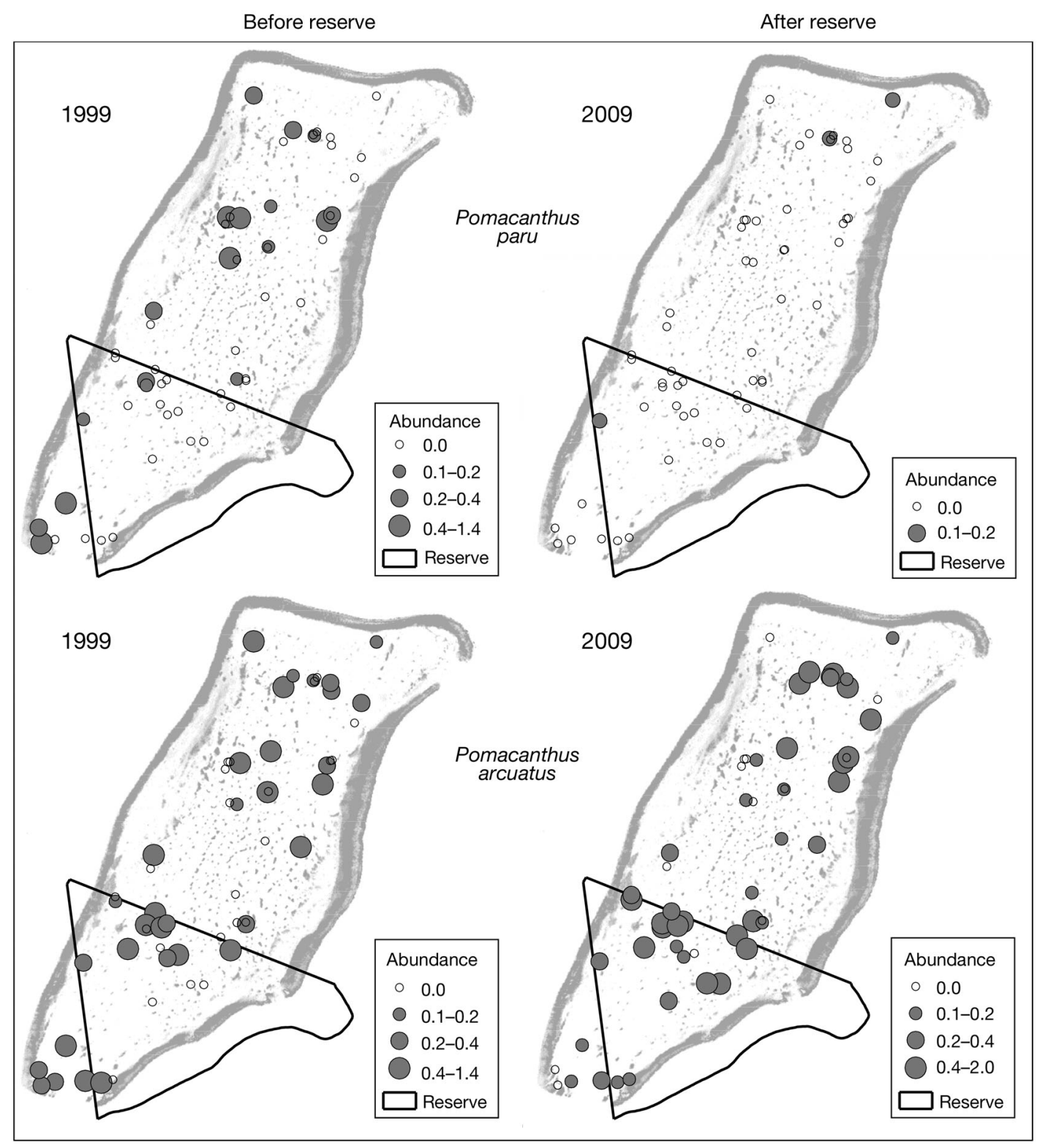

Fig. 4. Pomacanthus spp. Abundance of angelfish species P. paru (upper) and P. arcuatus (lower) at Glover's Reef Atoll, Belize, for periods before (left) and after (right) the reserve was implemented

to explain more of the variation in community structure ( $25 \%$ of variation explained) than the biological factors such as percent benthic substrate cover (19\% of variation explained). Such abiotic attributes are rarely controlled for in reserve design and monitoring (except see García-Charton et al. 2004, Kramer \& Heck 2007). Recent work has been done on the selection of reserve sites to protect the diversity of fish communities using similar abiotic and biotic habitat metrics as surrogates for the fish communities (Harborne et al. 2008b, Mumby et al. 2008). Our results imply that this approach may not be effective; although abiotic and biotic habitat factors are important, only $44 \%$ of the variability was explained by these factors. While the use of habitat metrics as surrogates is certainly more cost-effective than high-density sampling of fish abundances, further work should be done to confirm that such metrics are representative of fish community structure. If reserves are meant to be representative of fish community structure, it may be advisable to design them directly from fish community metrics.

Our finding that the effect of reserves can be either positive or negative, even for commercial fish species, is not surprising given the variability of marine reserve impacts reported in the literature. Maliao et al. (2009) found, in a meta-analysis of before-after, controlimpact studies on Philippine reserves, that exploited fishes did not significantly increase in abundance 
inside reserves. Micheli et al. (2004), in a meta-analysis of 31 reserves, showed that trophic level and fishing pressure explained only a very small percent of variation in species responses to reserves. They also found that strong declines in abundance within reserves occurred in an average of $19.2 \%$ of all species, and these were mostly non-commercial species. To our knowledge, the effects of initial distributions of fishes on response to reserve protection have not been incorporated into previous empirical studies of marine reserve impacts. We suspect that these distributions may be responsible for some of the variability in responses observed in these past studies.

Our study corroborates results from other studies reporting that larger bodied species and those of higher trophic levels tend to show more positive responses to reserve protection (Harborne et al. 2008a, Molloy et al. 2009). Predatory fish species have shown consistent and positive responses to reserve protection in studies of reserves in the Mediterranean Sea (Guidetti \& Sala 2007) and the Red Sea (Ashworth \& Ormond 2005). This pattern has also been documented in coral reef systems (Lamb \& Johnson 2010). Increased abundance of fishes of higher trophic levels is one possible explanation for the observed decreases in abundance of non-fished species in our study. A study on such trophic interactions is not possible given our data set, because many of the large-bodied, piscivorous species were difficult to detect with the visual methods used in our study. Some species of groupers and mackerels that are highly prized as commercial species were only observed at a single site, making it impossible to detect changes in abundance. Increased sample sizes and possibly an alternative sampling methodology would be needed to detect changes in abundance in these species. Overall habitat decline or change in environmental conditions may have been responsible for the observed declines in small noncommercial species; however, our analyses could not confirm this. The loss of coral cover does not seem to be a likely explanation, as we found no correlation between loss of coral and decreasing fish density. Paddack et al. (2009) also found that Caribbean fish species were slow to respond to loss in coral cover.

The marine reserve at Glover's Reef was originally implemented to protect conch and lobster biomass, and studies show that the reserve has succeeded in achieving this management goal (Acosta \& Robertson 2003, Lizama \& Gibson 2006). The reserve has also been effective in protecting rare species such as sharks, in part due to the gear restrictions in the fished area of the atoll (Pikitch et al. 2005). Stocks of threatened species of groupers have received protection through the implementation of a seasonal closure zone around known spawning areas since 2001. While our study found that the abundance of many commercial and non-commercial species declined over time at the GRMR, this does not necessarily imply that the reserve has failed to protect these species. We do not know whether declines in fish abundance would have been exacerbated in the absence of any reserve. Finally, it is expected that fish biomass would increase inside the reserve, but length data was not collected during the 1998 to 1999 study; therefore, our analyses and conclusions are limited only to trends in abundance.

Our study shows that knowledge of the pre-reserve distribution of fish species is critical to reserve design and monitoring. For target commercial species, such knowledge may help managers to predict whether or not populations will increase or decrease after reserve implementation. Given the lack of historical monitoring data for many reserve sites (Halpern 2003, Mascia 2003), use of the traditional ecological knowledge of fishermen and other stakeholders (Johannes 1998, Usher 2000) will be necessary to include in management planning. Fishers make observations on temporal and spatial scales of much finer resolution than those of scientists and managers, and their knowledge of local processes can be invaluable, particularly in coral reef ecosystems where both ecosystem and fishery processes are highly complex. Other authors have demonstrated how local knowledge can be useful to management in order to identify areas of high density of target fish species (Drew 2005, Cinner 2007), and such methods can be useful in reserve design and evaluation.

Despite the large and growing literature on fish movement, larval dispersal, and habitat usage, as well fishing fleet effort distributions (Hiddink et al. 2006, Kellner et al. 2007), homogeneous spatial distributions of both fish and fishing effort are often assumed in the modeling studies of marine reserves (Sanchirico \& Wilen 2001). Our study suggests that a lack of consideration of the spatial heterogeneity in marine systems may lead to unexpected negative impacts from marine reserves. Fishing effort displacement may override any positive benefits of reserves if the protected area is not highly productive (Hiddink et al. 2006), unless measures to restrict displacement are put into effect (Greenstreet et al. 2009). Reserve managers should monitor catch data for increasing mortality of species of commercial importance, as reserves alone may not ensure their protection. Because effort displaced from reserves may have a negative impact on fish in the surrounding fished zone, other management measures such as catch limits, protection of spawning areas, and gear restrictions may also be necessary. Inclusion of information on initial distribution of fishes, particularly during the process of reserve design and monitoring, will increase the utility of reserves as effective management tools. 
Acknowledgements. This work was funded by the Pew Institute for Ocean Science. Additional funding was provided by the University of Miami Fellowship to M.K. and B.E.H. and the Cooperative Unit for Fisheries Education and Research at the University of Miami. We thank the staff and scientists at the Wildlife Conservation Society in Belize for their assistance as we conducted our research in Belize. We also appreciate the efforts of D. Thoney and other staff and scientists who carried out the data collection at Glover's Reef Marine Reserve from 1998 to 1999. The Conservation Fund, Wildlife Conservation Society - Conservation Endowment Fund, and American Zoo and Aquarium Association provided financial support for the 1998 to 1999 data collection.

\section{LITERATURE CITED}

Acosta CA, Robertson DN (2003) Comparative spatial ecology of fished spiny lobsters Panulirus argus and an unfished congener $P$. guttatus in an isolated marine reserve at Glover's Reef atoll, Belize. Coral Reefs 22:1-9

Ashworth JS, Ormond RFG (2005) Effects of fishing pressure and trophic group on abundance and spillover across boundaries of a no-take zone. Biol Conserv 121:333-344

Azadivar F, Truong T, Jiao Y (2009) A decision support system for fisheries management using operations research and systems science approach. Expert Syst Appl 36:2971-2978

Babcock EA, Coleman R (2010) Length based indicators of finfish status at Glover's Reef Marine Reserve. Wildlife Conservation Society, Belize City

Bohnsack JA, Bannerot SP (1986) A stationary visual census technique for quantitatively assessing community structure of coral reef fishes. NOAA Technical Memorandum NMFS-41, National Oceanographic and Atmospheric Administration, Miami, FL

Botsford LW, Micheli F, Hastings A (2003) Principles for the design of marine reserves. Ecol Appl 13:25-31

Botsford LW, Brumbaugh DR, Grimes C, Kellner JB and others (2008) Connectivity, sustainability, and yield: bridging the gap between conventional fisheries management and marine protected areas. Rev Fish Biol Fish 19:69-95

Burnham KP, Anderson DR (2002) Model selection and multimodel inference: a practical information-theoretic approach. Springer Science, New York, NY

Chérubin LM, Kuchinke C, Paris CB (2008) Ocean circulation and terrestrial runoff dynamics in the Mesoamerican region from spectral optimization of SeaWiFS data and a high resolution simulation. Coral Reefs 27:503-519

Cinner JE (2007) Designing marine reserves to reflect local socioeconomic conditions: lessons from long-enduring customary management systems. Coral Reefs 26: 1035-1045

Conover WJ (1971) Practical nonparametric statistics. John Wiley \& Sons, New York, NY

> Côté I, Mosqueira I, Reynolds JD (2001) Effects of marine reserve characteristics on the protection of fish populations: a meta-analysis. J Fish Biol 59:178-189

Drew JA (2005) Use of traditional ecological knowledge in marine conservation. Conserv Biol 19:1286-1293

Dumas P, Bertaud A, Peignon C, Léopold M, Pelletier D (2008) A 'quick and clean' photographic method for the description of coral reef habitats. J Exp Mar Biol Ecol 368:161-168

Edgar GJ, Stuart-Smith RD (2009) Ecological effects of marine protected areas on rocky reef communities-a continental-scale analysis. Mar Ecol Prog Ser 388:51-62

Froese R, Pauly D (2010) FishBase. Available at: www.fishbase.org (accessed on 24 April 2010)
Garaway C, Esteban N (2002) The impact of marine protected areas on poorer communities living in and around them: institutional opportunities and constraints: Appendix 4case study of Glover's Reef Marine Reserve, Belize. DFID NRSP Project R7976, Department for International Development, London

- García-Charton JA, Perez-Ruzafa A, Sánchez-Jerez P, Bayles-Sempere JT, Reñones O, Moreno D (2004) Multiscale spatial heterogeneity, habitat structure, and the effect of marine reserves on western Mediterranean rocky reef fish assemblages. Mar Biol 144:161-182

Goñi R, Adlerstein S, Alvarez-Berastegui D, Forcada A and others (2008) Spillover from six western Mediterranean marine protected areas: evidence from artisanal fisheries. Mar Ecol Prog Ser 366:159-174

Greenstreet SPR, Fraser HM, Piet GJ (2009) Using MPAs to address regional-scale ecological objectives in the North Sea: modelling the effects of fishing effort displacement. ICES J Mar Sci 66:90-100

Grober-Dunsmore R, Frazer TK, Lindberg WJ, Beets J (2006) Reef fish and habitat relationships in a Caribbean seascape: the importance of reef context. Coral Reefs 26: 201-216

Guidetti P, Sala E (2007) Community-wide effects of marine reserves in the Mediterranean Sea. Mar Ecol Prog Ser 335: $43-56$

Halpern BS (2003) The impact of marine reserves: Do reserves work and does reserve size matter? Ecol Appl 13:117-137

> Halpern BS, Warner RR (2003) Matching marine reserve design to reserve objectives. Proc Biol Sci 270:1871-1878

Halpern BS, Gaines SD, Warner RR (2004) Confounding effects of the export of production and the displacement of fishing effort from marine reserves. Ecol Appl 14: 1248-1256

Harborne AR, Mumby PJ, Kappel CV, Dahlgren CP and others (2008a) Reserve effects and natural variation in coral reef communities. J Appl Ecol 45:1010-1018

Harborne AR, Mumby PJ, Kappel CV, Dahlgren CP, Micheli F, Holmes KE, Brumbaugh DR (2008b) Tropical coastal habitats as surrogates of fish community structure, grazing and fisheries value. Ecol Appl 18:1689-1701

Harmelin-Vivien M, Diréach LL, Bayle-Sempere J, Charbonnel E and others (2008) Gradients of abundance and biomass across reserve boundaries in six Mediterranean marine protected areas: Evidence of fish spillover? Biol Conserv 141:1829-1839

Heyman W, Requena N (2002) Status of multi-species spawning aggregations in Belize. The Nature Conservancy, Punta Gorda

Hiddink JG, Hutton T, Jennings S, Kaiser MJ (2006) Predicting the effects of area closures and fishing effort restrictions on the production, biomass, and species richness of benthic invertebrate communities. ICES J Mar Sci 63: $822-830$

Huntington BE, Karnauskas M, Babcock EA, Lirman D (2010) Untangling natural seascape variation from marine reserve effects using a landscape approach. PLoS ONE 5: e12327

Jennings S, Reynolds JD, Polunin NVC (1999) Predicting the vulnerability of tropical reef fishes to exploitation with phylogenies and life histories. Conserv Biol 13:1466-1475

Johannes RE (1998) The case for data-less marine resource management: examples from tropical nearshore finfisheries. Trends Ecol Evol 13:243-246

Kellner JB, Hastings A (2009) A reserve paradox: introduced heterogeneity may increase regional invasibility. Conserv Lett 2:115-122 
Kellner JB, Tetreault I, Gaines SD, Nisbet RM (2007) Fishing the line near marine reserves in single and multispecies fisheries. Ecol Appl 17:1039-1054

Kohler K, Gill S (2006) Coral Point Count with Excel extensions (CPCe): a Visual Basic program for the determination of coral and substrate coverage using random point count methodology. Comput Geosci 32:1259-1269

Kramer DL, Chapman MR (1999) Implications of fish home range size and relocation for marine reserve function. Environ Biol Fishes 55:65-79

Kramer KL, Heck KL Jr (2007) Top-down trophic shifts in Florida Keys patch reef marine protected areas. Mar Ecol Prog Ser 349:111-123

Lamb RW, Johnson DW (2010) Trophic restructuring of coral reef fish communities in a large marine reserve. Mar Ecol Prog Ser 408:169-180

Lester SE, Halpern BS, Grorud-Colvert K, Lubchenco J and others (2009) Biological effects within no-take marine reserves: a global synthesis. Mar Ecol Prog Ser 384: $33-46$

Leujak W, Ormond RFG (2007) Comparative accuracy and efficiency of six coral community survey methods. J Exp Mar Biol Ecol 351:168-187

Lizama D, Gibson J (2006) Report on the socioeconomic monitoring survey for Glover's Reef atoll, Belize. Wildlife Conservation Society, Belize City

Maliao R, White AT, Maypa AP, Turingan RG (2009) Trajectories and magnitude of change in coral reef fish populations in Philippine marine reserves: a meta-analysis. Coral Reefs 28:809-822

Mascia MB (2003) The human dimension of coral reef marine protected areas: recent social science research and its policy implications. Conserv Biol 17:630-632

Micheli F, Halpern BS, Botsford LW, Warner RR (2004) Trajectories and correlates of community change in no-take marine reserves. Ecol Appl 14:1709-1723

Molloy PP, McLean IB, Côté IM (2009) Effects of marine reserve age on fish populations: a global meta-analysis. J Appl Ecol 46:743-751

Editorial responsibility: Romuald Lipcius,

Gloucester Point, Virginia, USA
Mumby PJ, Broad K, Brumbaugh DR, Dahlgren CP and others (2008) Coral reef habitats as surrogates of species, ecological functions, and ecosystem services. Conserv Biol 22: 941-951

- Ordines F, Moranta J, Palmer M, Lerycke A, Suau A, MoralesNin B, Grau AM (2005) Variations in a shallow rocky reef fish community at different spatial scales in the western Mediterranean Sea. Mar Ecol Prog Ser 304:221-233

Paddack MJ, Reynolds JD, Aguilar C, Appeldoorn RS and others (2009) Recent region-wide declines in Caribbean reef fish abundance. Curr Biol 19:590-595

Pikitch EK, Chapman DD, Babcock EA, Shivji MS (2005) Habitat use and demographic population structure of elasmobranchs at a Caribbean atoll (Glover's Reef, Belize). Mar Ecol Prog Ser 302:187-197

R Development Core Team (2009) R: a language and environment for statistical computing. R Foundation for Statistical Computing, Vienna. Available at: www.R-project.org.

Russ GR, Alcala AC, Maypa AP, Calumpong HP, White AT (2004) Marine reserves benefits local fisheries. Ecol Appl 14:597-606

Sanchirico JN, Wilen JE (2001) A bioeconomic model of marine reserve creation. J Environ Econ Manag 42:257-276

Starr RM, Sala E, Ballesteros E, Zabala M (2007) Spatial dynamics of the Nassau grouper Epinephelus striatus in a Caribbean atoll. Mar Ecol Prog Ser 343:239-249

Stobart B, Warwick R, González C, Mallol S, Díaz D, Reñones O, Goñi R (2009) Long-term and spillover effects of a marine protected area on an exploited fish community. Mar Ecol Prog Ser 384:47-60

Thoney D (2001) Glovers reef survey in Belize, a multi-aquarium project. La surveillance du récif de Glovers à Bélize, un projet multi-Aquariums. Bull Inst Oceanogr (Monaco) 20:245-252

Usher PJ (2000) Traditional ecological knowledge in environmental assessment management. Arctic 53:183-193

Wallace RJ (1975) A reconnaissance of the sedimentology and ecology of Glovers Reef Atoll, Belize (British Honduras). $\mathrm{PhD}$ thesis, Princeton University, Princeton, NJ

Submitted: July 6, 2010; Accepted: March 25, 2011

Proofs received from author(s): June 6, 2011 